\title{
BRINGING THE HORIZON BACK IN: THE MID-RANGE APPROACH TO ORGANIZATIONAL STUDIES
}

\section{Peter Spink ${ }^{1}$}

\begin{abstract}
In recent years there has been a growing discussion of the lack of impact of organizational studies and, amongst other comments, on a drift away from the public sector agenda. Taking as a starting point two recent key addresses by James March and Jean-Claude Thoenig, both directed to organizational studies scholars, this paper seeks to contribute to this debate both in terms of focus and in terms of methodological approach. It argues in favor of a mid-range territorial focus on organizational affairs and to a place based action-investigation approach to methodology. In doing so it draws on the experience of the Center for Public Administration and Government of the Getulio Vargas Foundation in São Paulo with local level innovation during 1995 - 2008 and on a current project on urban vulnerabilities which has been largely shaped by these conclusions.
\end{abstract}

Keywords: Public Action; Community-based Research; Field Stations.

\section{TRAZENDO O HORIZONTE DE VOLTA : UMA ABORDAGEM MID- RANGE AOS ESTUDOS ORGANIZACIONAIS}

\section{Resumo}

Nos últimos anos tem havido uma discussão crescente sobre a falta de impacto dos estudos organizacionais e, entre outras observações, sobre um movimento a partir da agenda do setor público. Tomando como ponto de partida duas questões-chave colocadas por James March e Jean- Claude Thoenig, ambas dirigidas para estudos acadêmicos de organização, este trabalho busca contribuir para este debate, tanto em termos de foco e em termos de abordagem metodológica. Ele argumenta em favor de um enfoque territorial de médio alcance em assuntos organizacionais e para uma abordagem metodológica de ação-investigação. Ao fazê-lo, se baseia na experiência do Centro de Administração Pública e Governo da Fundação Getúlio Vargas em São Paulo durante 1995 - 2008 e em um

${ }_{1}^{1}$ Professor Titular da EAESP-FGV. E-mail: peter.spink@fgv.br 
projeto atual sobre vulnerabilidades urbanas que tem sido amplamente moldada por estas conclusões.

Palavras-chave: Ação Pública; Pesquisa de Base Comunitária; Estações de Campo.

\section{Introduction}

At the recent $1^{\text {st }}$ International Colloquium of Organizational Studies held in São Paulo (FGV-EAESP), Rafael Alcadipani asked why was it that the area of public administration had drawn away from organizational studies. His question - which served as a stimulus for this text - is intriguing for a number of reasons. Firstly, public sector questions were very present in the earlier studies on which the field was built; indeed where would the current debate on institutionalism be without TVA and the Grass Roots (SELZNICK, 1949)? Secondly there was never any significant ideological or epistemological rupture. Traditionalists and progressives, structuralists, post-constructionists and actor network theorists can be found in both. Thirdly, did anybody actually draw away or did both just drift apart and forget to converse? If so, can the conversation be recovered and, more importantly, is it worth the trouble?

Empirically there seems to be support for the drifting apart thesis; at least when taking into considerations observations of those who have considerable authority in the field (James March, 2007, from a US perspective and Jean-Claude Thoenig, one of the founders of EGOS, the European Group for Organizational Studies also in 2007). As to whether it is worth the trouble learning how to talk to each other, I would suggest thinking from Brazil and within the wider Latin America - that the answer is yes. The title for this text: bringing the horizon back in is a reference to a position that I started to put together at the first meeting of another group of organizational studies (1 ${ }^{\text {st }}$ ENEO, see RAC special number, vol.5, 2001) and has been further influenced by the work of the Public Management and Citizenship Program and the current work of the Center for Public Administration and Government on urban vulnerabilities and local development.

The argument I put forward is a simple one: 1) ordinary events do not float around in the air, they are grounded territorially and have horizons; 2) hence we need to relocate our analytical perspectives at the mid-range of ordinary events; 3 ) in order to do this we may have to give up the idea of being a discipline, or an inter-discipline or a trans-discipline and become post-disciplinary members of the broad humanities, 4) to perform our post-disciplinary sociality we will need to seek ways of linking investigation and action that are compatible and, more importantly in 
Brazil, contribute to a democratic place-based polity; or to expand on a concept of Selznick, an effective moral commonwealth (SELZNICK, 1992).

Today it is not easy to gain support for this position, especially considering that placed-based investigation-action requires commitment, lots of time, a readiness to be led in different directions than those initially imagined and the results are not easily chopped up into short and incisive journal articles. However it is worth noting that many of the foundational studies of the organizational field were the result of very significant investments in time: the field work for TVA study took two years; the Tavistock work in the Coal Fields of Northern England, Joan Woodward's pioneering work on technology and organization and the work of the Aston group were all programmatic in shape over a number of years; as were also the studies of Michel Crozier's organizational sociology center and the later work of Max Pages.

The text begins with the observations made by James March (2007) about the gradual loss of the moral and societal thrust of organizational studies that accompanied its relocation from more traditional university disciplinary departments to the business schools. Here it is not the business factor that is of concern, but the loss of the normative discussion that was always present in the humanities and - as they were called - the moral sciences. This was a theme that public administration never gave up debating and to which it regularly returns (WALDO 1948, DAHL 1947, FREDERICKSON 1990, WAMSLEY; WOLF, 1996). For a European standpoint, the text moves to the arguments of Jean-Claude Thoenig (2007). The choice of the two texts was not only because of their recent dates, but because both were produced for conferences of organizational schoolars.

In the second part, the focus is on the experience of the Public Management and Citizenship Program (SPINK, 2000) and the theme of innovation in public organizations (JACOBI; PINHO, 2006; FARAH; SPINK, 2008) and local responses to poverty reduction (CAMAROTTI; SPINK, 2000; SPINK; CAMAROTTI, 2007). From this, two important themes appear: the notion of public action as an aggregating concept for discussing the complexity of the contemporary social, economic and political scene at the mid-range level of action (including the role of business); the importance of seeing what is taking place from the point of view of what are at times very distinctive territorialities.

In the third part, public action will be looked at from what has been called its hybrid characteristics not only in terms of the different organizations present but also in terms of the different action languages that- at times cooperating, at times conflicting, at times merely coexisting - negotiate, impose and concomitantly perform very different realities (SPINK, 2012; SPINK; TOLEDO SILVA in press).

The final part takes the theme of public action languages back to the initial argument about the repositioning of organizational studies and 
argue for the importance of an alternative insertion in ongoing events, that recovers and connects the field station and extensionist approach of the fifties with the action-research approach of more recent years to produce an ethical posture of democratic and placed based investigation-action. Here I draw on an ongoing project in the area of urban vulnerabilities where multiple communities that were - for all practical effects - made invisible to the public eye and forced back onto their own resources in order to provide a minimum of services, are now facing the complex dynamics of being rediscovered by the local state.

\section{Two perspectives on Organizational Studies}

In 2006, James March was the invited speaker at the 2006 EGOS Colloquium, Bergen, Norway. The title of his address was "The Study of Organizations and Organizing Since 1945" (March 2007)2. The post II World War period was his starting point for the consolidation of organizational studies, but we can use the broader window of 1930 -1960 to remember that ideas are the product of multiple and fragmented conversations over time. It is here in the northern and western hemisphere that descriptive words such as business, firm, mill, foundry, factory, office, department, agency, shop, church, university, association, ministry and club begin to acquire a second attribute; that of being a constituent part of a new species: the organizations.

There was no radical and precise moment of truth in relation to this change; rather a gradual substitution or repositioning that would take the discussion about action in a variety of setting to become naturalized as a substantive noun ${ }^{3}$, an intrinsic part of a society now composed of individuals, groups and organizations (and later institutions). There is nothing special in this observation; modernity itself is marked by the growing reification of social categories, especially in the field of action (HABERMAS, 1984/1987). March divides the growth of organizational studies into two phases, one during the 1950s in the USA and the second in the 1960s-70s in Europe. Sociologists were important in the first phase and perhaps surprised by the sudden presence of large industrial firms, a permanent military complex and the large scale public service organizations, reached for the only item in the tool kit: the recently translated studies of Max Weber. However as we know, Weber did not discuss a type of organization, rather his concern was with forms of power and domination. But in the hands of others the association "organization + bureaucracy" created a naturalized program that continues to have impact today.

Note the use of the gerund - organizing - usually frowned on in portuguese.

Both Fayol for business administration and Willoughby for public administration used the expression

organizing as one of the atributes of managers or administrators during the early part of the $20^{\text {th }}$ century. 
As a young post-graduate and very junior research member of the Tavistock Institute, I was fortunate to be able to follow part of the second wave and listen to the discussions of those who formed EGOS in 1973. Many of them were academics who had gone through WWII and taken part in the massive use of science that would fuel Lerner and Laswell's new policy sciences (1951). Each major study that appeared opened new ground and created new arguments and at the Tavistock we were in the middle of the dispute about technology and the discussion on industrial democracy. Eric Trist's perspective on inter-organizational working tended towards the network approach present in the social and organizational ecology perspective (EMERY; TRIST, 1972) only to be counter argued by the equally excellent study by Michel Crozier and J-C Thoenig on the stable nature of the French decentralized administration (1976). At that time in Europe there very few university business schools and business courses were by and large given in technical schools.

As March argued in his address, researchers in organizational studies were usually members of the existing university departments: sociology, political science, social psychology and, little by little, social anthropology. Disciplinary based scholars are normally critical, usually independent and more often than not tend to be progressive. The business school boom, which took off in the USA and spread to most everywhere brought, as March argued, advantages and disadvantages. On the positive side: jobs, stability and research support ; as evidenced by the fact that today the greater part of organizational studies take part in business schools most of which are now university based. However, as he pointed out, the business school context is not a neutral one.

It encourages the mutual isolation of business school scholars of organizations and disciplinary scholars. Insofar as it encourages contact with the disciplines, it makes contact with ideas from economics more likely and contact with ideas from the sciences, psychology, sociology or political science less likely. It focuses research on the private sector, reducing the attention to institutions of the public sector that characterized much early work in the field. It brings an emphasis on the audience of practitioners, on finding the correlates of organizational performance rather than other organizational phenomena. It brings an orientation to the problems as possibilities of individual organizations (firms) and less attention to populations of organizations or to "organizing". It stimulates an emphasis on organizational strategies rather than societal strategies. (p.17) 
Here I would like to add a point not addressed by March, but implicit in his comments about business schools and another major shaper of the organizational studies agenda. Business schools are "management" schools, whether or not this is part of the name. They do not exist to teach people how to be good subordinates and shop floor workers, to be part of a community based collective, a horizontal economic fair trade network or a cooperative mutual aid society; they are about leadership and leading. People go to business schools to become managers either of their own or somebody else's enterprises. However if we accept that the capability of organizing is a collective competence intrinsic to social life, the naturalization of management as an inevitable feature of the day-to-day is by no means a simple issue. The same, incidentally, applies to the idea of self-managing teams who are seen as not having a manager because they are "capable" of "managing" themselves. It may be seen as natural, but in many places the move from administration to management also led from management to what Locke and Spencer (2011) call managerialism, the construction of a new professional caste.

In the same year that March addressed EGOS, Jean-Claude Thoenig, the first general secretary of EGOS in the 1970s also talked to a meeting of organizational scholars; this time in Mexico for the EGOS-LAEMOS meeting (THOENIG, 2007). The similarities and connections between the two talks are considerable; they come from different starting points but their conclusions and empirical observations overlap in many ways. Thoenig focuses on the way in which the sociological contribution to organizational studies was gradually pushed aside by the political economy of agency and neo-institutionalism. Similar to March, he also pointed to the growing importance of the professional schools (as opposed to the departments), the crisis in the humanities (which also affected public administration, as did the wave of managerialism in the 1980s) and, another key observation, the fact that published work from the 1990s onwards rarely included references to studies carried out before 1980 . The consequence was a significant reduction in papers and research studies in international organizational studies events, that were focused on the public sector. Taking as a comparison a four-year period in the 1980s and a similar period up to the year 2002, he commented that the percentage of public sector studies in EGOS dropped from $42 \%$ of all papers presented in the 1980s to only 7\% in the four years leading to 2002 .

In arguing for a return to the public sector tradition, Thoenig pointed to the importance of the public action perspective, within which the question of the "public" and "public affairs" is treated in a much broader way than that of statutes and laws.

The public service, both in the common law tradition and within the roman law perspective, does not have the monopolistic control of public affairs... from law and 
order, protection against fires, environmental policies to education, land use and social benefits. Hybrid institutional designs and vague statutes are common practice. [...] The State is far from being the Lord and Master and having exclusive control of public affairs, from the definition of what should be the object of action, to the design and implementation of the services themselves. (THOENIG, 2007, p.13)

As he continued, to enter this field, especially through themes such as territorial decentralization, intergovernmental relations and the implementation of policies requires opening up a much-needed creative and constructive dialogue between analyses of public policy and reflections about organizations of very different types. This is a topic to which I return in more detail in the next sections.

\section{Working with Innovations}

In 1995 the Center for Public Administration and Government at the Getulio Vargas Foundation, with support from the Ford Foundation, started what was to become a ten-year program to study innovation in Brazilian sub-national governments. The objective -coming at a time when there was much criticism about the capacity of local government - was to encourage states, municipalities and the original peoples own organizations to share the approaches they were using to solve public issues and respond to their communities needs. Its title, Public Management and Citizenship also made clear its concern with evaluating and disseminating those initiatives and knowledge being developed that could help to increase the effectiveness of public services and reduce inequality and social exclusion. It assumed, in other words, a normative and moral purpose to government activity; reducing inequality was not good because it reduced government spending or helped economic development, it was important because inequality and social exclusion was inacceptable 4 . Using as a research method the notion of an annual award and a very open and inclusive approach to entrants - all of which had to be from the public sector - the center was able to gather some 8,000 practical experiences of programs, projects and policies from all over the country, some of which went on to become key state and national policies, but nearly all producing some kind of effective response to local questions (see the web site: fgv.br/ceapg).

Many important themes emerged from this work which have been already reported on in various publications but four are important to this paper: 1) the reasons given for innovating; 2) the approach to planning

\footnotetext{
${ }^{4}$ As many authors have pointed out, this is perhaps the most special characteristic of the public sector and broader public action. Its justification is not economic but moral.
} 
and action 3) the different types of inter-organizational relationship present and 4) the importance of territoriality or to be more direct - place.

After several years we took a closer look at the reasons given for the program, project or activity being innovative. In marked contrast to the world of business, where being innovative is associated with being pioneering, being ahead of the field and being the first to do something, only $1 \%$ of the answers fell into this area. Some $58 \%$ of the answers could be broadly grouped as assuming the initiative in the search for new solutions to existing problems; $21 \%$ to changing the way of thinking about action and a further $19 \%$ to actively including communities and others in the collective search for action and in the co-management and monitoring of actions. New institutional arrangements were important for a further $11 \%$ and topics such as humanization of services, management solutions and technology transfer a further $12 \%$ (there were some multiple replies).

Secondly, in relation to planning and in keeping with observations by Behn (2008), none of the programs, projects and activities that we looked at which had made significant steps and created serious impact, had been conceived in the integrated manner that is proposed by international agencies. On the contrary, there had been a starting point, usually situated somewhere quite precise, a search for possibilities, replies, attempts in different directions, which had led to the construction of other possibilities. Along the way different actors were involved, other organizations appeared, topics were added or subtracted, alliances formed and objectives, goals processes and strategies constantly tweaked and changed. The common response tended to be "why not", "let's do something", "how about this".

The third point to emphasize is the presence of other organizations. In only $20 \%$ of the cases, action was the result of a single agency or department working alone. In the remainder, other organizations were present, sometimes other public organizations and departments (66\%) from the same or different jurisdictions and sometimes civil society, community and civic base organizations $60 \%$ ). In $46 \%$ of the cases, both were involved.

The fourth point draws the previous three together. When we looked both at the starting point (something very concrete that needed to be changed), the approach (let's start) and the different organizations that were drawn in along the way, the importance of the territory and place became very obvious. The civil society, community and civic organizations present were a broad range of those organizations and associations that can be found in most ordinary places. Residents and community organizations (11\%); local small businesses $(11 \%)$; public policy councils (9\%); catholic faith based organizations $(6 \%)$; professional associations including also Rotary, Lions (6\%); local voluntary services and NGOs (4\%); producers and farmers associations (4\%); local branches of trades unions (4\%); commercial associations (3\%); and many others. 
It is here where the importance of the public action framework comes in. The discussion of broad based civic action can be traced back beyond Ferguson's 1767 treatise on civil society, but it is in more recent years that this has been given more emphasis; largely within French sociology, as a way of taking a more complex look at how things happen. Here, for example, are Jean Dreze and Amartya Sen in the introduction to their classic, Hunger and Public Action (1989):

\begin{abstract}
By public action we mean not merely the activities of the state, but also social actions taken by members of the public - both "collaborative" (through civic cooperation) and "adversarial" (through social criticism and political opposition) .... The reach of public action goes well beyond the doings of the state, and involves what is done by the public - not merely for the public (DREZE; SEN, 1989).
\end{abstract}

During the 10 years of the Public Management and Citizenship Program there were countless examples of processes that had started somewhere and then grown on - some of them became major planks in national policy formation (such as minimum income payment, school grants and family health programs), but there were also many others that were simply highly effective at solving what they had set out to solve nothing more. The difference is subtle but important. As we had opportunities to discuss the work in other circles, including international events, we would often get questioned as to what evidence we had about whether experiences were replicable and how could they be "scaled up". The implication being that without evidence of these possibilities, the experiences being developed were of no relevance. At the beginning our answer was yes or may be, but eventually we learnt to also reply: "no idea - does it matter?"

Important in forming the last answer was another Ford Foundation supported project in which we looked closely at local initiatives in poverty reduction (CAMAROTTI; SPINK, 2000; SPINK 2003). These were practical experiences gathered from a number of sources being developed by municipal governments, NGOs and community movements, which were then debated in open meetings with activists, academics, members of the communities themselves and case-study researchers. Over 300 people were involved in the discussion of some eighty different experiences over three years. The major conclusions from this work were firstly that poverty manifests itself in the precarious presence of, and access to, goods and services and in the absence of effective channels of dialogue between those in power and the demands of the population. As a result, those better placed and more capably represented end up being able to claim a more significant part of goods and services. This can happen even within major government programs of support, for example to family agriculture 
and small businesses because of a lack of title deeds, documents, or even information. Secondly, was the importance of strong, autonomous and independent community groups, networks and social movements; what the USA community organizer Saul Alinsky would refer to as people's organizations (HORWITT, 1989). Thirdly was the same recurring theme of process before planning that had appeared in the public management and citizenship program.

Most important of all was the importance of a mid-range to social action. This was action that went beyond the micro-level actions of individuals and groups acting in solidarity, but was not the macro-level policy of national programs that were incapable of dealing with the complexity of local horizons. Many of the participants used the Portuguese word lugar (place) and working backwards from the discussions and examples we tried to describe what this meant to the many different participants. Conceptually, place was seen as "wherever we find ourselves", "it looks like ourselves" and was seen as formed by different interlocking arenas of demands, conflicts and claims for improvements. Place was also a dense concept, a reference for peoples lives in space and time that, depending on circumstances can be a neighborhood or a municipality, a river basin or a region. In geography, place has a very extensive bibliography (CRESSWELL, 2004; SANTOS, 2000) but for those involved it was a very workable expression; where the experiences, tactics, methods and practices root themselves. (In our current work in the south zone of São Paulo the same sense can be found: "this is my place, I want to see improvements but I don't want to leave it".)

In 2007, the CEAPG carried out a major study for UNICEF on the situation of children and adolescents in the semi-arid area of Brazil and again the theme of place and territoriality was a major player in the discussions of action (SPINK; CAMAROTTI, 2007). Here, despite the length and breadth of the semi-arid (covering a significant part of 11 states and more than 1.400 municipalities) there were again hundreds of very significant differences between one place and the other. Places where the catholic church's pastoral service for children was working with local government officials and community leaders to create new possibilities, places with one room schools and classes with children from 7 - 15 who were getting pupils into high school and university, but also places where nothing was happening.

With such variety and with so many different examples of people going ahead and making different futures happen for themselves - with all the practical difficulties - perhaps it is time to give more space to a set of ideas that were first discussed over fifty years ago and that are now being recovered. Horst Rittel discussed the idea of a wicked problem in a seminar that was reported in 1967 and later set out the argument with Melvin Webber in 1973. Wicked problems are difficult to solve because 
they are single and unique. There is no way to solve them by association from somewhere else, nor is it possible to verify the validity of a proposed solution, because there is nothing to compare it with. Wicked problems are only understood when they have been solved, for the solution points to the problem and not vice-versa ${ }^{5}$.

Many social issues are not wicked problems - even though they may feel like that - but some certainly are. Many of those involved in trying to find ways to deal with the issues that we identified in the innovations program and the linked studies were, for all practical purposes, working in a similar manner. That is solving place-based issues with place based actions derived from place based knowledge which may or may not be transferrable but is nevertheless valid.

\section{Public action and hybrid organizations}

The advantage of the public action framework is that firstly, it breaks open the ordered model of government action for the public good that is normally assumed by the dominant use of expressions such as public policy. Secondly, in opening up a much more dynamic and nonconsensual force field (actions by governments for citizens, actions by citizens for citizens and actions by citizens pressuring governments to act for citizens) it draws attention to the many different roles and connections possible between organizations.

Public policy is commonly seen as an authoritative stance assumed by a publicly and institutionally accountable set of people (executive, legislative or judiciary) in relation to a specific set of concerns (SALISBURY, 1968). It may be an explicit statement, or an implicit assumption, it may be a set of rules or decisions, or a program of actions, but in some way it refers to what governments choose to do; where they place their priorities and resources and where they do not (DYE, 1981). As Colebatch (1998) pointed outin his constructionist analysis of the term:

Policy conveys the sense that activity is deliberate and purposeful rather than erratic or random. Developing policy in relation to (say) the foreign language skills of young people or the future development of the economy or global climate change is an assertion of competence and rationality: these things will not just happen, but there will be a conscious ordering of activity to bring

\footnotetext{
${ }^{5}$ As they say: "To find the problem is thus the same thing as finding the solution; the problem can't be defined until the solution has been found [...] The formulation of a wicked problem is the problem" (1973, p.161)
} 
about outcomes that are in our best interest (COLEBATCH, 1998, p.72)

Public policy can be seen therefore as a social convention, as a way of expressing action and intentions and as a way of answering questions of the type "what are you going to do about such and such?" But it can also serve as the entry point to a very different set of questions, namely, "who determines what is going to be done about such and such and who determines how it will be done". Kingdon introduced the idea of agenda setting in 1984, to refer to the "list of subjects or problems to which governmental officials, and people outside of government closely associated with these officials, are paying some serious attention at any given time" (KINGDON, p. 3, 1995). Expressing the subject in these terms opens the question of "attention". Why should certain issues attract attention, what gets onto the agenda and, more importantly, who puts it there. Here a number of ideas have been formulated that have as their basis some variant on the notion of a policy community (JORDAN; MALONEY, 1997 or of an advocacy coalition, JENKINS-SMITH; SABATIER, 1993).

Pressure groups, lobbies, professional associations, academics, researchers, community organizers and many others are actively engaged in getting and keeping issues on the agenda and in influencing the way in which decisions are implemented not just in relation to major budget issues but, equally, if not more important, in relation to the myriads of day to day decisions. In his earlier discussion of street level bureaucracy, Lipsky (1980) was to point to the way in which the discretion and the relative autonomy available to street level public servants (those that directly serve the public) effectively meant that in a number of key areas, policy was much more a result of their local and collective consensus about what was possible and desirable than the result of senior government decision. In a similar way, he was later to point out (SMITH; LIPSKY, 1993) how the relation between public agencies, public non-profit service providers and their publics can also raise a number of policy formulation issues.

If public policy as looked at in this very brief manner is already cause for concern, then this concern becomes magnified when the different levels and branches of government are also taken into consideration. Very few countries have governance models that do not have some kind of sub national arrangement, be they unitary or federalist in inspiration. Indeed in many places "local" and "national" grew together, with the former often leading and the latter lagging as Polanyi's (1944) analysis of the UK poor laws in the nineteenth century well demonstrated. The result is a kind of three dimensional game of public action checkers in which pieces can be simultaneously moved by different actors and in which despite the apparent technical overtones of authoritative decision (that is, decision 
that carries institutional sanctions and responsibilities) and the rationality implied by the idea of a policy, it becomes very quickly clear that in the pushing and shoving of the public arena, there are no referees and very few rules. The language of public policy - as rhetoric - provides the idea of a moral high ground, that governments are serious and have intentions and that people can hold governments to their word; in practice most people get on with trying to make sure that resources and attention go to where they think it matters. They use the language of policy because that is the language that is currently in use; they do "policy work" (COLEBATCH; HOPPE; NOORDEGRAAF, 2010) because policy is an instrument of authority, of policy advisors, political decisions and resource allocations.

However, policy is not the only action language in use and, as mentioned, the term public is by no means restricted to the action of government. Government officials and agencies may look from their offices and imagine a spreading network of policy, inter-agency coordination, implementation and action moving outwards towards their fellow citizens and service users; perhaps a somewhat optimistic viewpoint given the very different views about the public that can be found between the lines of public administration (FREDERICKSON, 1991). But at the same time, their fellow citizens, looking at the same offices from the outside are more likely to see a world of questions, organizations and actions, some of which are private affairs, some of which are handled by different government agencies such as the state or region, the city, the county, the municipal government, the water board, the police and the fire department, some of which are somehow resolved by all sorts of mixtures of church, friends and relations, neighbors, clubs, associations and philanthropic bodies. In a number of cases the question of "who does what?" will be in dispute; either because this or that level, branch or agency of government doesn't do "its bit", or because it is "getting in the way".

The increasing use of the public action framework by Latin American scholars (for example CABRERA MENDOZA, 2005; FRANÇA FILHO, LAVILLE, MEDEIROS; MAGNEN, 2006) to refer to this tense, sometimes collaborative and often times conflictive area of multiple intersections between governmental action and public policy on the one hand and social movements and community action on the other, seems more than the simple getting together of public policy and social action. Indeed, there is not one public action arena but many. There are also many different notions of public present as well as many different notions of action often associated with equally different perspectives on power. Policy may be a common way of talking about this, but there are many other social languages present: that of the first ever public language, budgeting; the various views and practices of planning; the language of rights; that of laws and acts; direct mobilization on issues; concern with charity and 
everyday solidarity, amongst others (SPINK, 2013; SPINK; TOLEDO in press). Each in its different way enacts, or performs, public practices. Here it is important to stress that extending public action to the different activities that are being articulated in the public sphere and being carried out in reference to a common good (LABORIER; TROM, 2003), by no means implies consensus.

The use of public action as a lever to shift the focus and bring together what are often very different sides in an analytical equation, helps to understand why what previously were the indisputable roles and responsibilities of governmental technical bureaucracies are now increasingly seen as more common generic, societal problems in which the political institutions have a part but no longer have a monopoly. The way in which society is steering itself, specifically at the local level, is undergoing considerable change and, as the mobilizations and protests of June and July 2013 in Brazil suggest, these do not necessarily involve acts of cooperation or participation in invited forums. At the same time, new practices of coordination using networks, partnerships and deliberative forums, what Hirst (2000) has called "negotiated social governance" are growing in visibility. Found at the micro and mid range level of societal organization, within the places and spaces of daily horizons, they form as we found in the studies of innovation - an ongoing process of democratic experimentation involving a variety of different actors.

One question that follows is whether there is indeed a simple term that could be used to group all these different organizations together? Certainly it is tempting to see something of the broader, extensive and suggestive features of civil society as described by Dahrendorf (1996):

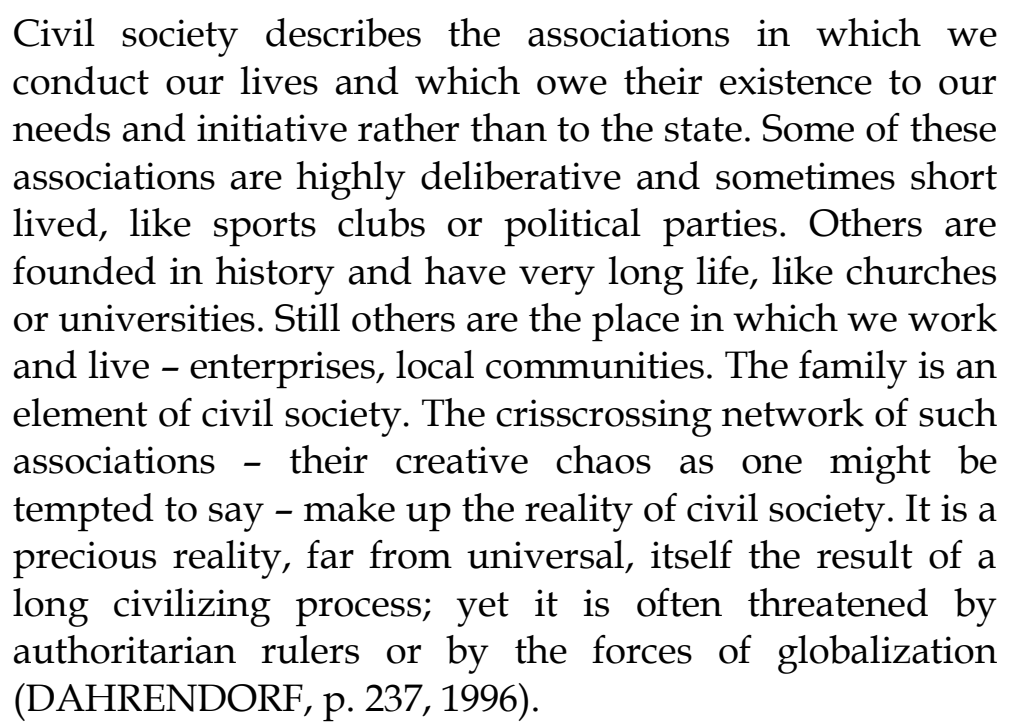

But does this mean cohesion and consensus? Seen in an open manner, the creative chaos is also made up of the tensions that surround the membership of these different organizations, but who assumes what role 
for what interest? In countries like Brazil, many of these organizations stood against each other during the difficult years of military rule and are now learning to build bridges. But is it the organizations themselves that matter or the values and wishes of their members as active agents? Do we give too much emphasis to the former and not enough to the latter? Dahrendorf places the university in civil society, certainly a location for which there is much historical evidence - but what does that mean for the way in which we carry out our studies?

As to the organizations themselves, they may individually have different statutes and legal arrangements, but as the work of the innovations program showed, they are increasingly likely to be found working together in some form of arrangement with organizations whose statutory base is different, whose approach to membership, governance, operational practices and purpose can be very different. Billis (2010), who has pioneered the study of hybrid organizations, argues that organizations have roots in either the public, private or voluntary (third) sectors with "fundamental and distinctly different governance and operational principles". They grow other attributes and what were once sharp distinctions become blurred in expressions such as "social enterprises". He points to five organizational elements that take different forms in different sectors: ownership, governance, operational priorities; human resources and other resources. Organizations that have their roots in one of the three different sectors will have different starting points and may acquire different practices as they learn to work together. In post 1988 Brazil, these distinctions, points of connection and indeed disconnection are very present, especially in various areas of health care, housing, education and civil defense - amongst others - where voluntary and on the ground local organizations, including a large number of faith based organizations (ROCHESTER; TORRY, 2010), have been key to providing initial responses.

\section{Repositioning Organizational studies: an example from the field of vulnerability and risk}

With support from the EAESP-FGV research fund, we have been putting some of these initial conclusions into practice in part of the immense and densely populated southern zone of São Paulo. Our overall programmatic concern is with the question of old/new urban vulnerabilities. They are old because many of them have been around for some time and also new, because these are now affected by the consequences of other actions, both locally, nationally and globally. This is an area that is very characteristic of the industrial boom in the 1960s and 1970s when, in the absence of any kind of significant state action and faced with the need to provide shelter for their families, both migrant and local workers moved to self construction as a solution (HOLSTON, 1991; 
KOWARICK, 2009; LARA, 2010; BAKER, 2012). With plots of land, formally or informally divided, or even if necessary in public areas that were not in use, families would start by digging a well and then little by little, one room would lead to another, a flat roof would serve for further additions and eventually water and power would be provided.

The focus of our concerns are the current challenges of urban vulnerability produced by the effects of continued increase in population density and housing deficit, difficulties in service provision, radical changes in the economic and labor market and local and global climate change. The consequence has been a vicious circle in which existing social and material vulnerabilities are sharpened by institutional vulnerabilities which both contribute to and amplify the effects of existing material and social vulnerabilities. In this setting and before the effective arrival of the local state, a number of community and faith based organizations had sought to articulate and provide some kind of service response. In some cases this led to significant innovations in a number of social areas including actions that were later adopted on a wider scale. In a number of communities, violence was also - and continues - to be a serious threat to everyday life and, again, it has been local and largely faith-based organizations that have sought to move along a different path from that of repression and police violence.

With the gradual arrival of public services and the different articulating councils for coordination, co-management \& consultation that were set out in both the 1988 constitution the early 1990s, the question arises of how these very different organizations and social actors will be able to work together. What kinds of collective governance are possible? Is it possible, as Callon, Lascoumes and Barthe (2011) have proposed in the technical field, to talk about hybrid forums.

Working with colleagues from São Paulo's Pontifical Catholic University (PUC-SP) whose focus is on people living in areas subject to water based risks (land slippage and flooding) we have been slowly putting together a interactive research program that draws from the action-research tradition and from the university extension or field station approach which was a feature of the University of California at Davies in the early 1950s. If, as the experience from the innovations studies suggested, developing knowledge is often a place based process that looks for problem resolution on issues that have a specific mid range origin and concern, then there is not much use in the classical applied research format of a general problem and a field site which is seen as providing a sample.

Place based research is therefore investigation based in and for a place, which may or may not have any use elsewhere, but it should certainly seek to be useful in the place where its based. For this ethical and pragmatic reason and no other, we switched the expression actionresearch around into investigation-action and sought an insertion in which 
the university, as an early member of civil society, could both ask questions and respond to the questions of others.

In our case, the discussion of place also involved a discussion about the notion of city, not as a given but as a heterogeneous set of networks and connection that, to use actor-network theory, are performed (LAW; MOLL, 2002; LATOUR, 2006; FARIAS, 2011; GRAU, INIGUEZ; SUBIRATS, 2011). In this sense the city is not a simple social construction but is constantly being produced through the collective action of sociomaterial networks in which participate objects, people, structures, institutions, systems of transport, technological networks and many different practices. In these different productions we can find bits and pieces of a commercial city, a financial city, a touristic city, a transport city, a territorial jurisdiction; a property market, a place to consume, a landscape of power, a place to reside, a city of ways of work, a public space for political action and protest: all multiple and simultaneous. Crisscrossing, connecting and disconnecting are the different languages of public action, also produced by and in different moments that perform different actors and practices. The language of the planner, of the annual budget, the languages of protest and direct action, of laws and the judiciary, and the different languages of place.

The south zone of São Paulo can be divided into three areas: the first is the south that starts at the Avenida Paulista and goes out past the parks and the various middle and upper middle class districts. The second covers what used to be the municipality of Santo Amaro (founded some 450 years ago and amalgamated into São Paulo in 1935), crosses the Pinheiros River and splits into two parts one on each side of the Guarapiranga reservoir basin and occupying a good part of the reservoir's water catchment area. As it crosses the river - over three different bridges - it materializes expressions that are often heard when talking about differences in public services and the style of police action: this side of the bridge; the other side of the bridge.

The CEAPG had made various contacts in this region over recent years which had led to discussions on social, material and institutional vulnerabilities. It was suggested we should talk to one of the faith-based organizations in the region, linked to the Santos Mártires Catholic Church ${ }^{6}$ in Jardim Ângela, one of the two districts of the M'Boi Mirim regional subprefecture. The Santos Mártires Society was set up in 1988 following the formation of the parish in 1987, to respond to an urgent need for very basic social services at a time when these were non existent in this region. The Society has a history of innovation in the social field and currently has 21 different units and services with 300 professionals and volunteers who attend more than 9,000 people every month on regular basis. Activities 
include child care facilities; a program of literacy for young people and adults; centers for children and adolescents; youth centers; shelters for children and adolescents; a center for women victims of violence; a service for social and legal support; outreach services to families living in highly vulnerable settings; a program of support for young people in conflict with the law; a day center for highly disabled children; a recycling unit and a bakery. A number of the services created by the Society, including a very successful program for drug abuse in young people, went on to form part of broader public health and social programs.

Linked to the Church and the Society are a number of important social forums that gather together activists and representatives of different public organizations, service providers and universities concerned with social change. The most well known of these is the Forum in Defense of Life (Forum em Defesa da Vida), which has been meeting on the first Friday of every month since it was created in February 1997. At the time there had been a radical increase in violence in the region and Jardim Ângela had been declared the most violent place in the world (UN May 1996). The Forum serves as a horizontal gathering point to talk about social issues in the region and connects many key local actors with other institutional representatives (such as sub-prefecture; public prosecutors office; state secretary of public security; school directors; social service coordinators).

Following a numbers of visits and discussions with the Society's coordinating group and its directors, we set out a joint program of investigation. There were a number of questions that the Society wanted to work on or have help with: it was their $25^{\text {th }}$ year and they wanted to pull the different parts of their history together including their archives; most of their services were now supported through contracts with the São Paulo Municipal Government which meant new approaches to coordination especially in education and social work. They had also produced a pilot questionnaire with basic social and occupation information to help characterize the different populations that were being attended and needed help to analyze and also improve the questionnaire. Our concerns were with the intersection of social, material and institutional vulnerabilities with a focus, where possible, on people living with water-based risks (heavy rains, slippage and flooding). The area of M'Boi Mirim has at 50 areas that have been diagnosed as "at risk". We proposed that by helping the Society with their questions we could probably learn a lot about our questions and that we were also very willing to help with information on other innovations and generally be useful - which is precisely what is happening.

Documenting the history of the Society has meant lots of conversations with early residents of the region (the ones that dug wells and then started bit by bit to build their houses together with their churches), with young people who grew up in the parish and then went on to university at night or to technical school and are now taking part in 
the coordination of the various services; with those who led the social movements for land and services and others that were involved in creating what were, to return to the innovations program conclusions, new approaches to existing problems. Contacts with those involved in the different services are bringing in newer issues as are the contacts being made through the forum with other university and institutional actors present. New strands of work have been opened up more specifically focused on youth and on women victims of violence; both areas where there are connections with previous studies and experiences that the CEAPG has documented. Re-locating part of the CEAPG in time focus and place, has also made it much easier to pick up on the more institutional questions of civil defense and risk management, because we have begun to at least get some idea of what "placed based knowledge" might be and to understand the social, material and institutional issues that crisscross different environmental approaches: indeed a wicked problem.

When we began this work, we did what any other academic research group would do with access to the Internet and to public sector documents and data. We set out to learn from the numbers and from the public sector information available. The results, from what we found and - more importantly - didn't find, have led to a different angle on the question of vulnerability: that of the ways in which institutional vulnerability can directly affect social vulnerability of populations by turning them "invisible". If the visitor to São Paulo was to talk to most people in the first of the three southern areas about the second and third, the impression would be that yes there are people out there, but that is the periphery of the town (periphery being the outward fringe). Even the portal of the Municipal Government will say on the page introducing the sub-prefectures: "few people know, but São Paulo has 31 small 'municipalities' distributed throughout the city". (the commas around municipalities are from the original text).

Jardim Ângela together with Jardim São Luís form one of these small "municipalities": M'Boi Mirim. Together there are over 600,000 inhabitants, which would make it one of the thirty largest municipalities in the country. The whole area of the two south zones that surround the Guarapiranga Reservoir and make up a large part of its catchment basin has just over two million inhabitants (larger than the State of Rondonia). Very few people talk about M'Boi Mirim as a place, they talk about three areas, Jardim Ângela, Jardim São Luis and Capão Redonda (which is part of another prefecture) or about their own neighborhood. But they will talk about $\mathrm{M}^{\prime}$ Boi as the road - the only road - that goes through the center of the region and leads people to the train/bus network in Santo Amaro. When the M'Boi stops, nobody goes anywhere. Public services are unequally distributed - when they exist - and often have serious staff shortages. There are positive advances in health and education but even here there is hardly any on the ground coordination and vertical 
coordination uses different territorial demarcations even within the municipal government. Public security and policing are a São Paulo State responsibility which brings yet another territorial demarcation. The only public libraries are in the three new multipurpose primary and middle schools which are open during weekdays from $8.00-6.00$; the others are voluntary; one is maintained by one of the two community police bases, others are in the churches.

A recent document published by the Municipal Secretary for Social Assistance and Development (SMADS) analyzing the different regions of São Paulo states that in the region of M'Boi Mirim, some $36 \%$ of the population can be classified as being in high and very high vulnerability, which rises to $50 \%$ in Jardim Ângela. The description continues with an appraisal of social services:

In relation to the network of social services, the area of the sub prefecture has 79 different service units capable of attending together 16,610 clients and is the most well equipped of the southern zone 1 . Of these units the Municipality directly runs three (2 CRAS and 1 CREAS). Amongst the services that are contracted, the major part is focused on children and adolescents

The three service units run directly by the municipality are the coordinating units for social welfare (known as reference centers in the terminology of the SUAS). A simple calculation shows that the remainder - seventy-six - are run by other organizations in the region; that were there long before the effective arrival of the local state and the new social welfare system.

Being in a setting characterized by social and material vulnerability is serious enough, especially when the institutional framework has great difficulty in meeting the challenges that need to be faced. However being in a setting that is also to a certain extent invisible to those who can and do play a major role in determining government action takes vulnerability into a very different dimension - and certainly one which has very little to do with the current international development agency based debate on urban resilience.

Maps are powerful players in building social realities (WOOD, 1992). Most maps of São Paulo don't include this broader southern area for it is presumed that, as one of the most frequent guides to the expanded center of the town comments, "it is in the central region where the greater part of the traffic circulates". It is only recently in 2013, following massive protests over public transport in June and July, that the major São Paulo news and traffic radio traffic channels have begun to talk about the $\mathrm{M}^{\prime}$ Boi Mirim Avenue. The São Paulo city web site has no effective place based maps showing the location of services, at best there is a list of addresses. 
As in many other places in Brazil, people move around by word of mouth, which has led us into some very new and at the same time old questions about civil society and the way communities build themselves and provide for their needs. It has led us to recognize the very key role that can be played by parishes and the congregations, not just in Jardim Ângela, but elsewhere, in holding life together in very different spaces and places. It has led to questioning about the way in which forms of municipal organization and service provision can, inadvertently, lead to producing and maintaining - that is directly performing - the invisibility of the other. Certainly enough questions to keep organizational studies going for a number of years - especially if we try to be useful at the same time.

\section{References}

BAKER, J. L. (Ed). Climate change, disaster risk and the urban poor. Washington DC: The World Bank, 2012.

BEHN, R.D. The adoption of innovation: the challenge of learning to adapt tacit knowledge. In : SANDFORD, B. (Org.). Innovations in government: research, recognition and replication. 1ed.Washington DC: The Brookings Institution, 2008, p. 138 - 158.

BILLIS, D. Towards a theory of hybrid organizations. In: BILLIS, D. (Org.)

Hybrid organizations and the third sector: challenges for practice, theory and policy. London: Palgrave Macmillan, 2010, p. 46- 69

CABRERA MENDOZA, E. Acción publica e desarollo local. Mexico, D.F.: Fondo de Cultura Economica, 2005.

CALLON, M.; LASCOUMES, P.; BARTHE, Y.Acting in an uncertain world: a essay on technical democracy. Cambridge Mass.: the MIT Press, 2011.

CAMAROTTI, I.; SPINK, P. K. Estratégias locais para a redução da pobreza: Construindo a Cidadania. São Paulo: FGV/EAESP, 2000.

COLEBATCH, H.K. Policy. Buckingham: Open University Press, 1998.

COLEBATCH, H.K.; HOPPE, R.; NOORDEGRAAF, M. Working for policy. Amsterdam: Amsterdam University Press, 2010.

CRESSWELL, T. Place: a short introduction. Oxford: Blackwell, 2004.

CROZIER, M; THOENIG, J-C. The regulation of complex organized systems. Administrative science quarterly. v. 21, p. 547- 570, 1976. 
DAHL, R. The Science of Public Administration: three problems. Public Administration Review. v. 7, n. 1, p. 1-11, 1947.

DAHRENDORF, R. Economic opportunity, civil society and political liberty. Development and Change, v. 27, n. 2, p. 229-249, 1996.

DREZE, J.; SEN, A. Hunger \& public action. London: Clarendon Press, 1989.

DYE, T. R. Understanding public policy. Englewood Cliffs, NJ: Prentice Hall, 1972.

EMERY, F .E.; TRIST, E L. Towards a social ecology. London: Plenum Press, 1972.

FARAH, M. F. S.; SPINK, P. K. Subnational Government Innovation in a Comparative Perspective: Brazil. In: SANDFORD, B. (Org.). Innovations in Government: Research, Recognition and Replication. Washington DC: The Brookings Institution, 2008, p. 71-92.

FARÍAS, I. Ensamblajes urbanos: la TAR y el examen de la ciudad. Athenea Digital, v. 11, n. 1, p. 15-40, 2011.

FRANÇA FILHO, G. C.; LAVILLE, J-L.; MEDEIROS, A.; MAGNEN, J-P. Ação pública e economia solidária: uma perspectiva internacional. Porto Alegre: Editora da Universidade Federal de Rio grande do Sul, 2006.

FREDERICKSON, H.G. Public Administration and Social Equity. Public Administration Review, v. 50, n. 2, p. 228-237, 1990.

FREDERICKSON, H.G. Towards a theory of the public for public administration. Administration \& Society, v. 22, n. 4, p. 395-417, 1991.

GRAU, M.; ÍNIIGUEZ, L.; SUBIRATS, J. ¿Cómo gobernar la complejidad? Invitación a una gobernanza urbana híbrida y relacional. Athenea Digital. Revista de Pensamiento e Investigación social, v. 11, n. 1, p. 63 - 84, 2011.

HABERMAS, J. The theory of communicative action. Vols. I \& II. Cambridge: Polity Press, 1984/1987.

HIRST, P. 2000 Democracy and Governance. In: Jon Pierre (Ed.) Debating Governance: Authority, Steering and Democracy. Oxford: Oxford University Press, 2000.

HOLSTON, J. Autoconstruction in Working-Class Brazil. Cultural Anthropology. v. 6, n. 4, p. 447-465, 1991.

HORWITT, S. D. Let them call me rebel: Saul Alinsky, his life and legacy. New York: Alfred A. Knopf, 1989. 
JACOBI, P.; PINHO, J. A. (orgs) Inovação no campo da gestão pública local: novos desafios, novos patamares. Rio de Janeiro: Editora FGV, 2006.

JENKINS-SMITH, H.C.; SABATIER, P. The study of public policy processes. In P.A. SABATIER, P.; JENKINS-SMITH, H.C. (eds). Policy change and learning: an advocacy coalition approach. Boulder Col.: Westview Press, 1993. p. 1-12

JORDAN,G.; MALONEY, W. A. Accounting for sub governments: explaining the persistence of policy communities. Administration \& Society. v. 29, n. 5, p. $557-583,1997$.

KINGDON, J.W. Agendas, alternatives and public policies. New York: Addison-Wesley, 1995.

KOWARICK, L. Viver em risco: sobre a vulnerabilidade socioeconomic e civil. São Paulo: Editora 34, 2009.

LABORIER, P.; TROM, D. (Org). Historicités de l'action publique. Groupe de sociologie politique et morale - Centre universitaire de recherches administratives et politiques de Picardie. Paris: PUF, 2003.

LARA, F. L. The Form of the Informal: Invesigating Brazilian Self-Built Housing Solutions. In:HERNANDÉZ, F.; KELLETT, P.; ALLEN, L. K. (eds) Rethinking the Informal city: critical perspectives from latin america. New York: Berghahn Books, 2010.

LATOUR, B. Reassembling the social: an introduction to Actor-NetworkTheory. Oxford University Press, 2006.

LAW, J.; MOL, A. (orgs). Complexities: social studies of knowledge practice. Durham NC: Duke University Press, 2002.

LERNER, D.; LASSWELL, H.D. The policy sciences: recent developments in scope and methods. Stanford, Cal.: Stanford University Press, 1951.

LIPSKY, M. Street-level bureaucracy: dilemmas of the individual in public services. New York: Russell Sage Foundation, 1980.

LOCKE, R. R.; SPENDER, J-C. Confronting managerialism: how the business elite and their schools threw our lives out of action. London: Zed Books, 2011.

MARCH, J. G. The study of organizations and organizing since 1945. Organization studies, v. 28, n. 1, p. 9-19, 2007.

POLANYI, K. The great transformation. Boston: Beacon Press, 1944. 
RITTEL, H. W. J.; WEBBER, M.V. Dilemmas in a General Theory of Planning. Policy sciences 4. p. 155-169, 1973.

ROCHESTER, C.; TORRY, M.Faith-based organizations and hybridity: A special case? In: BILLIS, David (Org.) Hybrid organizations and the third sector: challenges for practice, theory and policy. London: Palgrave Macmillan, 2010, p. 46- 69.

SALISBURY, R.H. 1968. The analysis of public policy: a search for theory and roles. In: RANNEY, A. (ed) Political science and public policy. Chicago: Markham, 1968, p. 151-178.

SANTOS, M. Território e sociedade: Entrevista com Milton Santos. São Paulo: Editora Fundação Perseu Abramo, 2000.

SELZNICK, P. TVA and the Grass Roots. Berkeley, Cal.: University of California Press, 1949.

SELZNICK, P. The moral commonwaelth: social theory and the promise of community. Berkeley, Cal.: University of California Press, 1992.

SMITH, S. R.; LIPSKY, M. Nonprofits for hire: the welfare state in the age of contracting. Cambridge Mass.: Harvard University Press, 1993.

SPINK, P.K. The rights approach to local public management: Experiences from Brazil. Revista de Administração de Empresas, v. 40, n.3, p. 45-65, 2000 .

SPINK, P.K. O Lugar do lugar na análise organizacional. Revista de Administração Contemporânea, v. 5, p. 11-34, 2001.

SPINK, P.K. Poverty and place. In: CARR, S.; SLOAN, T. (eds). Poverty and psychology: from global perspective to local practice. New York: Kluwer Academic/ Plenum Publishers, 2003, p.103-122.

SPINK, P. K. Psicologia Social e políticas públicas: linguagens de ação na era dos direitos. In: MARQUES, E.; FARIA, C. A. P. (Orgs). A política pública como campo multidisciplinar. São Paulo: Editora UNESP, 2013, p. 155-180.

SPINK, P. K.; CAMAROTTI, I. Crianças e adolescentes: situação no semiárido Brasileiro. São Paulo/Brasilia: Programa Gestão Pública e Governo/Unicef, 2007.

SPINK, P. K.; TOLEDO SILVA, G. (in press) A(s) Política(s) pública(s) e as linguagens da Ação Pública To be published In: LOUREIRO, M.R.; TEIXEIRA, M.A. (orgs). Políticas públicas e o desenvolvimento brasileiro. São Paulo: Editora FGV. 
THOENIG, J-C. Recuperando a ênfase na dimensão pública dos estudos organizacionais. Revista de Administração Pública. Edição Especial Comemorativa, (1967 - 2007), v. 41, p.9-36, 2007.

WALDO, D. The administrative state: a study of the political theory of American Public Administration. New Brunswick: Transaction Publishers, 1948.

WAMSLEY, G.L.; WOLF, J. E. Refounding democratic public administration: modern paradoxes. Thousand Oaks, Cal.: Sage Publications, 1996.

WOOD, D. The power of maps. New York: The Guilford Press, 1992. 